Article

\title{
Effect of Casuarina Plantations Inoculated with Arbuscular Mycorrhizal Fungi and Frankia on the Diversity of Herbaceous Vegetation in Saline Environments in Senegal
}

\author{
Pape Ibrahima Djighaly $1,2,3,4, * \mathbb{C}$, Daouda Ngom ${ }^{5}$, Nathalie Diagne ${ }^{1,3,4, *}$, Dioumacor Fall ${ }^{1,3}$, \\ Mariama Ngom ${ }^{1,5,6}$, Diégane Diouf ${ }^{7}$, Valerie Hocher ${ }^{6}$, Laurent Laplaze ${ }^{1}{ }^{\oplus}$, Antony Champion ${ }^{8}$, \\ Jill M. Farrant ${ }^{9}$ (D) and Sergio Svistoonoff ${ }^{6,8}$ (D) \\ 1 Laboratoire Commun de Microbiologie (LCM) Institut de Recherche pour le Développement/Institut \\ Sénégalais de Recherches Agricoles/Université Cheikh Anta Diop, (IRD/ISRA/UCAD), Centre de Recherche \\ de Bel Air, Dakar BP 1386, Senegal; dioumacorfall@yahoo.fr (D.F.); maringom@hotmail.fr (M.N.); \\ laurent.laplaze@ird.fr (L.L.) \\ 2 Département d'Agroforesterie, Université Assane Seck de Ziguinchor, Ziguinchor BP 523, Senegal \\ Centre National de Recherches Agronomiques (ISRA/CNRA), Bambey BP 53, Senegal \\ 4 Laboratoire Mixte International Adaptation des Plantes et Microorganismes Associés Aux Stress \\ Environnementaux (LAPSE), Centre de Recherche de Bel Air, Dakar BP 1386, Senegal \\ 5 Département de Biologie Végétale, Université Cheikh Anta Diop de Dakar, Dakar BP 5005, Senegal; \\ ngom_daouda@yahoo.fr \\ 6 Laboratoire des Symbioses Tropicales et Méditerranéennes (LSTM), (IRD/INRA/CIRAD/Université de \\ Montpellier/Supagro), IRD TA A-82/J, Campus International de Baillarguet, 34398 Montpellier CEDEX 5, \\ France; valerie.hocher@ird.fr (V.H.); sergio.svistoonoff@ird.fr (S.S.) \\ 7 UFR Environnement, Biodiversité et Développement Durable, Université du Sine Saloum El Hadj Ibrahima \\ Niass (USSEIN), Kaolack BP 55, Senegal; diegane.diouf@ucad.edu.sn \\ 8 Institut de Recherche pour le Développement (IRD), Unité Mixte de Recherche DIADE (Diversité \\ Adaptation et Développement des plantes) 911 avenue Agropolis, BP 64501, 34394 Montpellier CEDEX 5, \\ France; antony.champion@ird.fr \\ 9 Department of Molecular and Cell Biology, University of Cape Town, Private Bag, Rondebosch 7701, \\ South Africa; jill.farrant@uct.ac.za \\ * Correspondence: djighaly@yahoo.fr (P.I.D.); nathaliediagne@gmail.com (N.D.)
}

Received: 29 February 2020; Accepted: 24 April 2020; Published: 27 July 2020

\begin{abstract}
Land salinization is a major constraint for the practice of agriculture in the world. Considering the extent of this phenomenon, the rehabilitation of ecosystems degraded by salinization has become a priority to guarantee food security in semi-arid environments. The mechanical and chemical approaches for rehabilitating salt-affected soils being expensive, an alternative approach is to develop and utilize biological systems utilizing salt-tolerant plant species. Casuarina species are naturally halotolerant, but this tolerance has been shown to be improved when they are inoculated with arbuscular mycorrhizal fungi (AMF) and/or nitrogen-fixing bacteria (Frankia). Furthermore, Casuarina plantations have been proposed to promote the development of plant diversity. Thus, the aim of the current study was to evaluate the impact of a plantation comprising the species Casuarina inoculated with AMF and Frankia on the diversity of the sub-canopy and adjacent vegetation. Work was conducted on a plantation comprising Casurina equisetifolia and C. glauca variously inoculated with Frankia and Rhizophagus fasciculatus prior to field planting. The experimental area of $2500 \mathrm{~m}^{2}$ was divided into randomized blocks and vegetation sampling was conducted below and outside of the Casuarina canopy in $32 \mathrm{~m}^{2}$ plots. A total of 48 samples were taken annually over 3 years, with 24 taken from below the Casuarina canopy and 24 from outside the canopy. The results obtained show that co-inoculation with Frankia and Rhizophagus fasciculatus improves the height and survival rate of both species. After $4-5$ years, there was greater species diversity and plant biomass in the sub-canopy
\end{abstract}


environment compared with that of the adjacent environments. Our results suggest that inoculation of beneficial microbes can improve growth of Casuarina species and that planting of such species can improve the diversity of herbaceous vegetation in saline environments.

Keywords: Casuarina; salinization; diversity; rehabilitation; herbaceous vegetation

\section{Introduction}

Land salinization is characterized by high plant mortality, loss of biodiversity, and loss of soil fertility [1]. Acidic and hyper-saline halomorphic soils occupy more than $85 \%$ of the land in Palmarin (Fatick, Senegal) [2].

In recent years, an increase in salinity combined with the impacts of climate change has led to the decrease of agricultural yields. In Senegal, the area of Fatick is one of the regions most affected by salinization, and in the village of Palmarin, the agricultural production systems are threatened by the salinization of the land. Rice cultivation, which was practiced in Palmarin in the 1960s, has been abandoned because of the lack of rainfall and the increasing salinity of the land.

The increasing decline in arable land needed to provide food security for this population is exacerbated by the increasing population in this area. Official estimates taken between 1988 [3] and 2015 [4] suggest an annual growth rate of $2.72 \%$. The lack of potential income from this area has furthermore increased the phenomenon of rural exodus, especially among the local youth [5].

It thus becomes essential to implement low-cost, ecological strategies to rehabilitate ecosystems and improve ecosystem benefits (e.g., firewood, fodder, and timber production). The use of salt-tolerant species of the Casuarinaceae family in association with symbiotic microorganisms could be a bio-remediation strategy [6,7]. Casuarinaceae form root nodules in association with the nitrogen-fixing actinobacteria Frankia, which enables survival in nutrient-poor soils. Furthermore, they can develop a symbiotic association with arbuscular mycorrhizal fungi (AMF) and ectomycorrhizal fungi (EM), which enhance plant water absorption and promote the uptake of nutrients, particularly, phosphorous and nitrogen [8-10]. Inoculation with salt-tolerant AMF and bacteria can improve plant salinity tolerance [11] and enhance nutrient acquisition, plant growth, and yield [12,13]. Economically, Casuarinaceae species are valued for the density of their wood and for facilitating nitrogen fertilization of soils through their symbiotic association with the soil bacteria Frankia [14].

What is also of importance is the regeneration of natural herbaceous vegetation in salt-affected areas, so as not to ultimately lose the natural diversity is this region. This in turn could be of reciprocal benefit. The positive effect of herbaceous vegetation on tree growth under saline conditions has been described for Prosopis juliflora and Vachellia seyal seedlings [15]. Thus, the hypothesis of our study is that salt-tolerant Casuarina species could have a positive effect on herbaceous diversity and reduce soil salt concentrations, thereby collectively improving growth.

To test this hypothesis, field plantations of C. equisetifolia and C. glauca, species which have been tested under controlled conditions for their ability to tolerate salt stress [7], were established in 2013. Subsequent to this, we studied (i) the effect of inoculation (Rhizophagus fasciculatus/Frankia strain CeD) on the growth of $C$. equisetifolia and C. glauca under saline environments and (ii) the impact of planting on herbaceous vegetation diversity after four years of planting in saline conditions.

Our data showed a beneficial effect of Casuarina on the diversity of hebaceous vegetation and that inoculation has a positive effect on wood production. We thus propose that the establishment of the vegetation layer through these programs could improve biogeochemical cycles, carbon fluxes that significantly influence the soil microbial community $[16,17]$. 


\section{Materials and Methods}

\subsection{Field Study Site}

The experimental plantation where the work was conducted is located in the Fatick region (Senegal) in the municipality of Palmarin, $14^{\circ} 01^{\prime} 14 \mathrm{~N}$ and $16^{\circ} 45^{\prime} 23 \mathrm{~W}$ (Figure 1). The plantation has a surface area of $2500 \mathrm{~m}^{2}$ and the soil has a sandy loamy texture (analysis performed by the INP "National Institute of Pedology"). The annual rainfall is between $400 \mathrm{~mm}$ and 900 mm isohyets (Figure A1) and the study site is subject to periodic waterlogging during the rainy season. Soil salinity levels vary from 40 to $500 \mathrm{mM}$ in the dry season. Due to its geographical location, which gives it the character of a peninsula, the temperature in the municipality of Palmarin varies between $16{ }^{\circ} \mathrm{C}$ in January and $38^{\circ} \mathrm{C}$ in June.

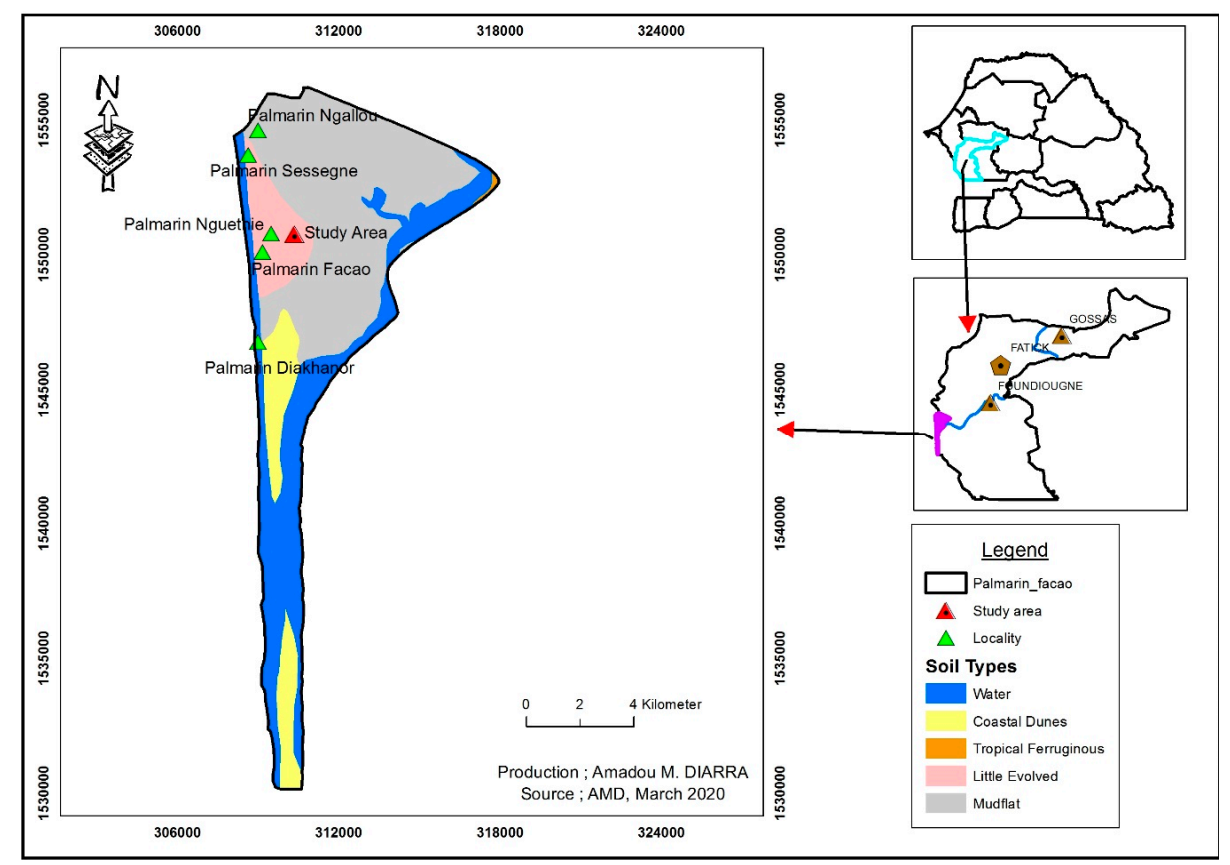

Figure 1. Map of the study site in Palmarin (Fatick, Senegal).

\subsection{Experimentation in the Field}

The Casuarina plantation was established in 2013 and is composed of Casuarina glauca and Casuarina equisetifolia which were planted according the experimental designed shown in Figure 2. Prior to field establishment, plants were inoculated with an AMF (Rhizophagus fasciculatus (Thaxt.) C. Walker \& A. Schüßler strain DAOM227130 isolated in Quebec) according to Djighaly et al. [7] and Frankia (CeD) strain isolated by Diem et al. [18] from C. equisetifolia as described in Ngom et al. [19]. The AMF (R. fasciculatus) and Frankia strain CeD were selected on the basis of previous studies showing their ability to enhance the growth of C. equisetifolia and C. glauca under salt conditions [7,20]. The bacterial inoculum for growth of Frankia was prepared by culture under propionate medium (BAP) [16] for 4 days to obtain a phase of exponential bacterial growth. The plants were inoculated with $5 \mathrm{~mL}$ of this liquid culture (absorbance $=0.02$ ) and the AMF inoculum containing $32 \mathrm{spores} / \mathrm{g}$ and $80 \%$ mycorrhized roots. Plants were inoculated 21 days after seeding with the following combinations: (1) plants inoculated with with $R$. fasciculatus (Rf) only, (2) plants inoculated with Frankia (CeD) only, and (3) plants co-inoculated with Rf and Frankia. Non-inoculated plants were used as controls. After 4 months in the nursery, the seedlings were transferred to the field. The experimental design included 4 blocks (each row of $82 \times 10$ subplots in Figure 2), each treatment was replicated 4 times (1 replicate per block), and in each replicate 10 plants were planted. A spacing of $2 \mathrm{~m} \times 2 \mathrm{~m}$ between the plants was left (Figure 2). A total of 320 plants were transferred to the plot. 


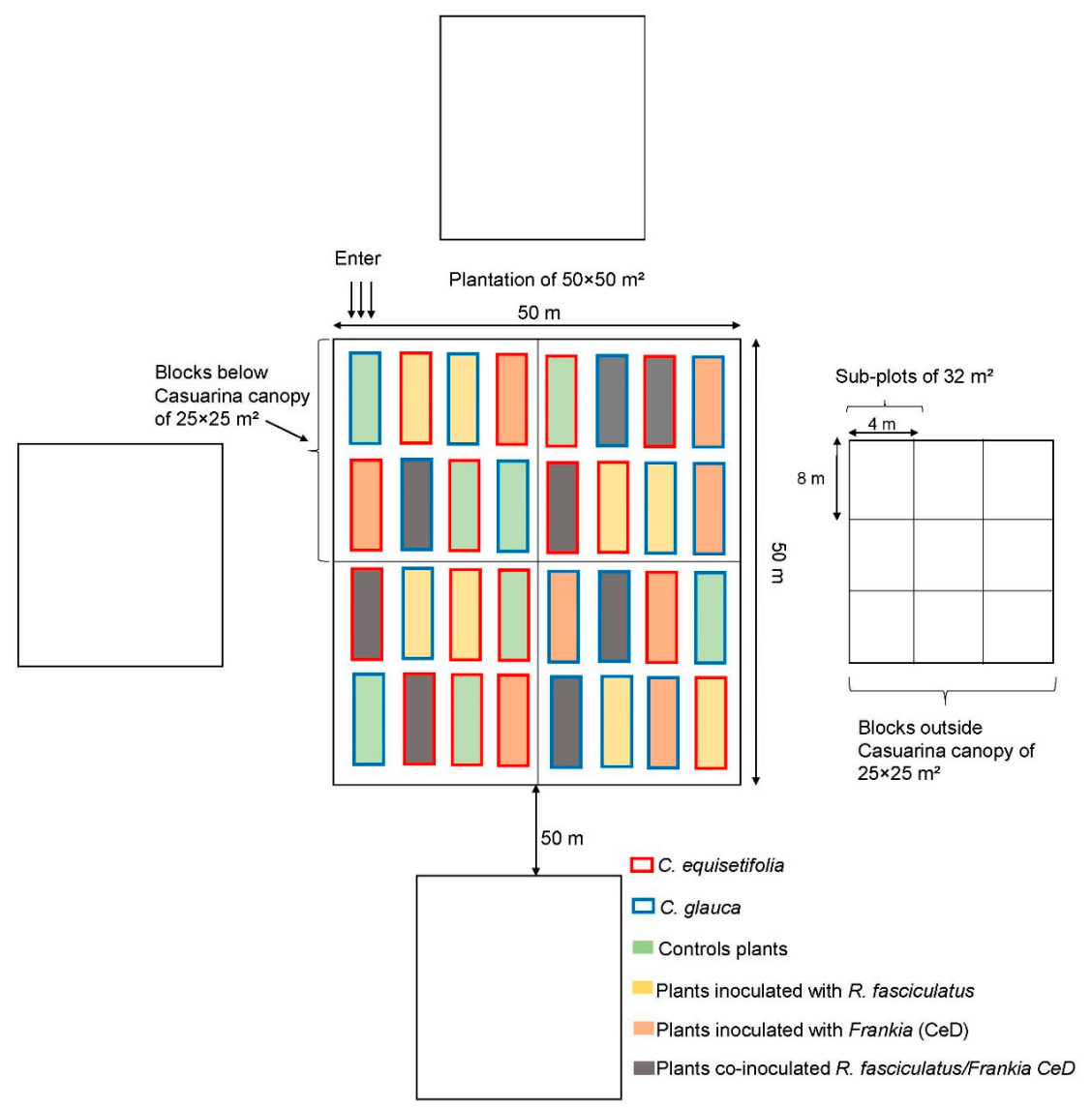

Figure 2. Experimentation design.

\subsection{Physicochemical Characterization of the Site}

The physical and chemical characteristics of the soil were determined at the sites before planting. Four soil samples were taken at depths of between 0-20 cm from the east, west, north, and south directions. At least 3 samples were pooled per replicate from each sampling point. Soil chemical parameters such as $\mathrm{pH}$, salinity, N, C, and P were analyzed at the LAMA ("Laboratoire des Moyens Analytiques"), certified ISO 9001 version 2000.

The height and collar diameter of the plants were measured using a tape measure. This was performed after 6 months, 2 years, and 3 years to assess plant growth rates. Plant survival rate was determined by counting using the formula:

$$
\text { Survival rate }(\%)=(\text { number of surviving plants }) /(\text { total number of plants }) \times 100
$$

\subsection{Diversity of Herbaceous Vegetation}

An inventory of plants growing in the $2500 \mathrm{~m}^{2}$ plantation was undertaken 3 years after planting to limit the disturbances linked to the transplanting of the Casuarina trees, but also to allow the planted Casuarina to reach a size big enough to have an impact on the fertility of the soil and the diversity of the environment. A comparison was made between the plots below the Casuarina canopy and outside the Casuarina canopy. To do this, the plantation was divided into four blocks of $25 \times 25 \mathrm{~m}^{2}$ (Figure 2). In each block, $32 \mathrm{~m}^{2}$ sub-plots were delimited, which is the minimum area with saline land at Palmarin. The surveys were carried out using the Braun-Blanquet [20] phytosociological method. Each species inventoried was given an abundance-dominance coefficient (+ to 5), which was transformed into percentages using the method of Gillet [21].

A total of 48 vegetation surveys were carried out, including 24 below the Casuarina canopy, randomly distributed in each block $\left(25 \times 25 \mathrm{~m}^{2}\right)$ to take into account the heterogeneity of the 
environment. A comparison was made with 24 surveys outside the Casuarina canopy distributed into four blocks in eastern, western, northern, and southern directions. Botanical samples were identified in the field or in the laboratory using the flora of Senegal [22]. The species names were updated on the basis of the list of flowering plants in tropical Africa from Lebrun and Stork $[23,24]$. The diversity of herbaceous vegetation below and outside the Casuarina canopy was evaluated after 3 years (2016), 4 years (2017), and 5 years (2018) of planting.

\subsection{Diversity and Regularity Indices}

\subsubsection{Shannon-Weaver Index}

The Shannon index $\left(\mathrm{H}^{\prime}\right)$ is used to calculate the level of species diversity in a given environment. It takes into account not only the number of species, but also the distribution of individuals within these species. It is often between 0 and 4.5, rarely higher [25]. It is calculated using the following equation:

$$
\mathrm{H}^{\prime}=-\sum(\mathrm{ni} / \mathrm{N}) \log _{2}(\mathrm{ni} / \mathrm{N})
$$

where ni is the abundance of species $i$; $N$ is the total abundance.

\subsubsection{Evenness Measure}

Evenness expresses the distribution of species within the association. It varies between 0 and 1 , is without units, and corresponds to the ratio of Shannon index $\left(\mathrm{H}^{\prime}\right)$ and maximum value of Shannon index $\left(\mathrm{H}^{\prime}\right.$ max $)$ :

Evenness is represented as follows:

$$
\mathrm{E}=\left(\mathrm{H}^{\prime}\right) /\left(\mathrm{H}^{\prime} \max \right)
$$

where $\mathrm{H}^{\prime} \max =\log _{2}(\mathrm{ni} / \mathrm{N})$.

\subsubsection{Jaccard's Similarity Index}

The Jaccard similarity index allows a comparison between two sites, as it assesses the similarity between two surveys by relating the species common to both surveys to those specific to each survey. Jaccard's similarity index is represented as follows:

$$
J=a /(a+b+c)
$$

where $\mathrm{a}$ is the number of species present in both samples (joint occurrences), $\mathrm{b}$ is the number of species present in sample one, and $\mathrm{c}$ is the number of species present in sample two.

\subsubsection{Specific Presence Contribution (S.P.C.)}

It is the ratio expressed as a percentage between the centesimal frequency of this species and the sum of the centesimal frequencies of all species; it reflects the participation of the species in covering the soil surface [26].

$$
\operatorname{Csi}(\%)=(\mathrm{Fsi} / \Sigma \mathrm{Fsi}) \times 100
$$

where Fsi is the specific frequency of species $i ; \Sigma F s i$ is the sum of the frequency of all species; and Csi is the specific contribution of species $i$.

\subsection{Biomass}

The above-ground biomass of the sub-canopy and adjacent herbaceous vegetation was estimated within the $1 \mathrm{~m}^{2}$ blocks by the integral harvesting method [27]. These plots were randomly distributed 
within the $32 \mathrm{~m}^{2}$ plots. A total of 48 plots of $1 \mathrm{~m}^{2}$ were used to evaluate the plant mass, 24 of which were below the Casuarina canopy and 24 others outside the Casuarina canopy.

The harvesting method consisted of harvesting the entire plant and subsequent separation into tissue types. The fresh mass of tissues was determined in the field using a spring scale. The dry mass was obtained after drying in an oven at $70{ }^{\circ} \mathrm{C}$ until a constant weight was obtained. Production is expressed in tonnes of dry biomass per hectare ( $\mathrm{t} \mathrm{DB} / \mathrm{ha})$.

Specific Contribution Biomass (Csib)

This measure reflects the participation of a species in above-ground plant biomass and is calculated as

$$
\text { Csib }(\%)=(W s i b / \Sigma W s i b) \times 100
$$

where Wsib is the weight of dry biomass of the species ib; $\Sigma$ Wsib is the total weight of dry biomass of all species; and Csib is the specific contribution of biomass ib [26].

\subsection{Statistical Analysis}

Data collected were processed using R software version 3.4.2. Normality of all data sets was assessed using the Shapiro-Wilk test and the equality of variances by the Levene test. For data following normal laws, a two-way ANOVA was performed to evaluate the effects of inoculation and species on survival rate, height, and collar diameter. Chemical parameters, coverage, specific richness, Shannon index, and dry biomass were also analyzed with Bonferonni test with a significance threshold set at 0.05 . We analyzed species composition below and outside Casuarina canopy as a function of years using non-metric multidimensional scaling (NMDS).

\section{Results}

\subsection{Physicochemical Characteristics of Soil}

Four composite soil samples were taken at horizons of $0-20 \mathrm{~cm}$ before planting and 3 years after planting. The 2013 planting site had salt concentrations of approximately $0.53 \%$ o before planting. This concentration decreased significantly 3 years after planting to $0.28 \%$ o at the end of the dry season. The soil had an average carbon content of $2.15 \mathrm{~g} / \mathrm{kg}$, nitrogen content of $155.75 \mathrm{mg} / \mathrm{kg}$, and phosphorus content of 42.25 before planting. This content increased to $3.3 \mathrm{~g} / \mathrm{kg}, 275 \mathrm{mg} / \mathrm{kg}$, and $170 \mathrm{mg} / \mathrm{kg}$ respectively for carbon, nitrogen, and phosphorus 3 years after planting (Table 1 ). The $\mathrm{pH}$ of the site was acidic; approximately 5.3 and 5.95 before planting and 3 years after planting, respectively (Table 1).

Table 1. Chemical characteristics of soil before planting in 2013 and 3 years after planting. Lower-case letters $(a-b)$ indicate significant differences between before planting and 3 years after planting.

\begin{tabular}{cccccc}
\hline Analysis & $\mathrm{pH}$ & Salinity & Nitrogen Kjeldahl & Carbon Organic & Phosphorus Total \\
\hline Before planting & $5.3 \mathrm{a}$ & $0.45 \mathrm{a}$ & $155.75 \mathrm{~b}$ & $\mathrm{~g} / \mathbf{k g}$ & $\mathbf{m g} / \mathbf{k g}$ \\
\hline $\begin{array}{c}\text { 3 years after planting } \\
\text { (below Casuarina canopy) }\end{array}$ & $5.95 \mathrm{a}$ & $0.28 \mathrm{~b}$ & $275 \mathrm{a}$ & $3.3 \mathrm{a}$ & $42.25 \mathrm{~b}$ \\
\hline
\end{tabular}

3.2. Effect of Inoculation with AMF/Frankia on the Growth of C. equisetifolia and C. glauca Planted in the More Saline Area in Palmarin

The effects of inoculation of these species in terms of survival and growth rates are given in Table 2. After 6 months of planting, in C. equisetifolia, all plants that were co-inoculated had survived, with those inoculated by Frankia or Rf only showing $80 \%$ and $77 \%$ survival, respectively. In C. glauca, higher survival rates occurred in plants inoculated with Frankia (93.34\%) compared to those inoculated with Rf only $(90 \%)$ or co-inoculated ( $87 \%)$. Two years after planting, a decrease in the survival rate was 
observed in both species. The highest survival rate of $67.5 \%$ was obtained in co-inoculated and Frankia only inoculated C. glauca. Compared to control plants, co-inoculation improved survival rates by $20 \%$ and $12.5 \%$ in C. equisetifolia and C. glauca, respectively (Table 2). In C. equisetifolia, the lowest survival rates were observed in the control plants, with $30 \%$ of the plants surviving. Of the 320 plants initially transplanted, 53\% survived after 3 years (Table 2). Inoculation did not improve survival in C. glauca 3 years after planting. However, it did improve the survival rate of C. equisetifolia.

Table 2. Effect of inoculation with $R$. fasciculatus and Frankia on the survival rate and height of $C$. equisetifolia and C. glauca plants under saline stress conditions 6 months, 2 years, and 3 years after planting. Control, Rf: R. fasciculatus, Frankia: Frankia strain CeD, and Rf + Frankia: AMF/Frankia co-inoculation. Lower-case letters (a-e) indicate significant differences between control and inoculated plants for each time (6 months, 2 years, and 3 years).

\begin{tabular}{|c|c|c|c|c|c|}
\hline & Species & Treatments & Survival Rate (\%) & Height (cm) & Collar Diameter $(\mathrm{cm})$ \\
\hline \multirow{11}{*}{$\begin{array}{l}6 \text { months after } \\
\text { planting }\end{array}$} & \multirow{4}{*}{ C. equisetifolia } & Control & $85 \mathrm{~b}$ & $65.14 \mathrm{de}$ & $5.45 \mathrm{a}$ \\
\hline & & Frankia & $80 \mathrm{~b}$ & 68.94 cde & $6.13 \mathrm{a}$ \\
\hline & & $\mathrm{Rf}$ & $76.67 \mathrm{~b}$ & $60.51 \mathrm{e}$ & $6.05 a$ \\
\hline & & $\mathrm{Rf}+$ Frankia & $100 \mathrm{a}$ & $73.67 \mathrm{bcd}$ & $5.15 \mathrm{a}$ \\
\hline & \multirow{4}{*}{ C. glauca } & Control & $73.4 \mathrm{~b}$ & $78.51 \mathrm{abc}$ & $5.75 \mathrm{a}$ \\
\hline & & Frankia & $93.34 \mathrm{a}$ & $79.10 \mathrm{abc}$ & $6.02 \mathrm{a}$ \\
\hline & & $\mathrm{Rf}$ & $90 \mathrm{a}$ & $81.98 \mathrm{ab}$ & $5.51 \mathrm{a}$ \\
\hline & & $\mathrm{Rf}+$ Frankia & $86.67 \mathrm{ab}$ & $88.00 \mathrm{a}$ & $6.21 \mathrm{a}$ \\
\hline & Species & & . & $* * *$ & ns \\
\hline & Inoculation & & ** & $* *$ & ns \\
\hline & Species*Inoculation & & $\mathrm{ns}$ & $\mathrm{ns}$ & ns \\
\hline \multirow{11}{*}{2 years after } & \multirow{4}{*}{ C. equisetifolia } & Control & $30 \mathrm{c}$ & $107.81 \mathrm{c}$ & $12.26 \mathrm{a}$ \\
\hline & & Frankia & $55 \mathrm{~b}$ & $111.77 \mathrm{c}$ & $13.87 \mathrm{a}$ \\
\hline & & $\mathrm{Rf}$ & $47.5 \mathrm{~b}$ & $168.13 \mathrm{ab}$ & $13.45 \mathrm{a}$ \\
\hline & & $\mathrm{Rf}+$ Frankia & $50 \mathrm{~b}$ & $172.26 \mathrm{ab}$ & $13.49 \mathrm{a}$ \\
\hline & \multirow{4}{*}{ C. glauca } & Control & $55 \mathrm{~b}$ & $144.40 \mathrm{~b}$ & $11.30 \mathrm{a}$ \\
\hline & & Frankia & $67.5 \mathrm{a}$ & $141.29 \mathrm{~b}$ & $12.31 \mathrm{a}$ \\
\hline & & $\mathrm{Rf}$ & $45 \mathrm{~b}$ & $181.05 \mathrm{a}$ & $15.00 \mathrm{a}$ \\
\hline & & $\mathrm{Rf}+$ Frankia & $67.5 \mathrm{a}$ & $166.98 \mathrm{ab}$ & $12.30 \mathrm{a}$ \\
\hline & Species & & * & * & ns \\
\hline & Inoculation & & $* *$ & $* * *$ & $\mathrm{~ns}$ \\
\hline & Species*Inoculation & & . & . & ns \\
\hline \multirow{11}{*}{3 years after } & \multirow{4}{*}{ C. equisetifolia } & Control & $30 \mathrm{~b}$ & $125.63 \mathrm{c}$ & $13.55 \mathrm{a}$ \\
\hline & & Frankia & $55 \mathrm{a}$ & $127.45 \mathrm{c}$ & $14.07 \mathrm{a}$ \\
\hline & & $\mathrm{Rf}$ & $47.5 \mathrm{a}$ & $180.13 \mathrm{ab}$ & $14.86 \mathrm{a}$ \\
\hline & & $\mathrm{Rf}+$ Frankia & $50 \mathrm{a}$ & $186.88 \mathrm{ab}$ & $14.63 \mathrm{a}$ \\
\hline & \multirow{4}{*}{ C. glauca } & Control & $55 \mathrm{a}$ & $152.77 \mathrm{bc}$ & $12.97 \mathrm{a}$ \\
\hline & & Frankia & $57 \mathrm{a}$ & $163.29 \mathrm{abc}$ & $15.33 \mathrm{a}$ \\
\hline & & $\mathrm{Rf}$ & $45 \mathrm{a}$ & $196.50 \mathrm{a}$ & $16.52 \mathrm{a}$ \\
\hline & & $\mathrm{Rf}+$ Frankia & $57.5 \mathrm{a}$ & $192.38 \mathrm{a}$ & $15.40 \mathrm{a}$ \\
\hline & Species & & . & * & ns \\
\hline & Inoculation & & $*$ & $* * *$ & ns \\
\hline & Species*Inoculation & & ns & . & $\mathrm{ns}$ \\
\hline
\end{tabular}

ns, no significant difference; ${ }^{*}, * *$ and ${ }^{* * *}$ indicate significant difference at $p<0.1,0.05,0.01$, and 0.001 , respectively. 
In terms of the effect of inoculations on plant growth, there was no significant increase in the height of the C. equisetifolia plants compared to control plants 6 months after planting. However, significantly greater heights were observed in C. glauca that were co-inoculated compared to the control plants. After 3 years, plants of both species that were inoculated with Rf and co-inoculated had greater heights than control plants. However, inoculation did not significantly increase collar diameter compared to control plants during 3 years of planting.

\subsection{Effect of the Casuarina Plantation on Species Diversity and Specific Contribution below and outside Their Canopy}

The herbaceous vegetation of the site comprises 37 species from 28 genera and 14 families (Table 3). Below the Casuarina canopy, 24, 29, and 33 species were inventoried in 2016, 2017, and 2018, respectively. From outside the canopy, 21, 22, and 24 species were inventoried in 2016, 2017, and 2018, respectively. Of the 37 species inventoried, 14 were common in all areas. The species specifically inventoried below the Casuarina canopy in 2018 were Ipomoea sinuata Ort., Corchorus tridens L., and Melochia corchorifolia (L.).

Table 3. Presence/absence and specific contribution presence below the Casuarina canopy (BCC) and outside the Casuarina canopy (OCC).

\begin{tabular}{|c|c|c|c|c|c|c|c|c|}
\hline \multirow[t]{2}{*}{ Family } & \multirow[t]{2}{*}{ Genera } & \multirow[t]{2}{*}{ Species } & \multicolumn{3}{|c|}{ BCC } & \multicolumn{3}{|c|}{ OCC } \\
\hline & & & 2016 & 2017 & 2018 & 2016 & 2017 & 2018 \\
\hline \multirow{15}{*}{ Poaceae } & Dactyloctenium & Dactyloctenium aegyptium (L.) Willd & 0.64 & 2.96 & 2.12 & 6.03 & 3.40 & 3.87 \\
\hline & \multirow{2}{*}{ Schisachyrium } & Schizachyrium compressa (K. Schum.) & 3.21 & 2.59 & 5.30 & - & - & - \\
\hline & & Schizachyrium rupestre (Stapf.) Stapf & - & - & - & 0.86 & 2.04 & 1.66 \\
\hline & \multirow{2}{*}{ Chloris } & Chloris prieurii Kunth & 3.85 & 3.33 & 3.53 & 3.45 & 3.40 & 5.52 \\
\hline & & Chloris barbata (L.) Sw. & - & 2.96 & 2.12 & - & - & - \\
\hline & Pennisetum & Pennisetum polystachion (L.) Schul. & - & 3.70 & 3.53 & 2.59 & 4.76 & 4.97 \\
\hline & \multirow{3}{*}{ Eragrostis } & Eragrostis tenella (L.) Beauv. & 5.13 & 2.96 & 1.41 & - & - & - \\
\hline & & Eragrostis tremula Hochst. Ex Steud. & 3.85 & 4.07 & 2.12 & 5.17 & 4.76 & 4.97 \\
\hline & & Eragrostis aspera (Jacq.) Nees. & 3.21 & 3.70 & 1.77 & - & - & - \\
\hline & Paspalum & Paspalum vaginatum (L.) & 4,49 & 3.33 & 3.53 & - & - & - \\
\hline & \multirow{2}{*}{ Aristida } & Aristida funiculata Trin. \& Rupr. & - & 2.96 & 3.53 & 5.17 & 5.44 & 1.10 \\
\hline & & Aristida mutabilis Trin. \& Rupr. & - & 1.11 & 2.47 & - & - & - \\
\hline & Digitaria & Digitaria horizontalis Willd. & 3.85 & 2.96 & 2.47 & 1.72 & 6.12 & 6.08 \\
\hline & Brachiaria & Brachiaria lata C.E. Hubb. & - & 0.37 & 0.71 & - & - & - \\
\hline & Sporobolus & Sporobolus robustus Kunth & 5.77 & 8.15 & 7.07 & 3.45 & 6.80 & 3.87 \\
\hline \multirow{4}{*}{ Malvaceae } & \multirow{2}{*}{ Hibiscus } & Hibiscus rostellatus (Guill. \& Perr.) & 0.64 & 1.48 & 1.41 & - & - & - \\
\hline & & Hibiscus asper Hook. & 3.21 & 3.33 & 7.42 & 3.45 & 2.72 & - \\
\hline & Corchorus & Corchorus tridens L. & - & - & 0.71 & - & - & - \\
\hline & Sida & Sida alba L. & 4.49 & - & - & 3.45 & 5.44 & 3.87 \\
\hline \multirow{3}{*}{ Cyperaceae } & Fuirena & Fuirena ciliaris (L.) Roxb. & 2.56 & - & - & 0.86 & 0.68 & 5.52 \\
\hline & \multirow{2}{*}{ Cyperus } & Cyperus esculentus L. & 1.92 & 4.07 & 2.47 & - & 4.76 & 3.31 \\
\hline & & Cyperus bulbosus Vahl. & 3.21 & 2.22 & 1.06 & 5.17 & 4.08 & 2.76 \\
\hline \multirow{2}{*}{ Amaranthaceae } & Amaranthus & Amaranthus greacizans L. & 0.64 & 3.70 & 3.89 & 6.03 & 2.04 & 2.21 \\
\hline & Philoxerus & Philoxerus vermicularis (L.) Sm. & 8.33 & 3.33 & 8.13 & 17.24 & 16.33 & 12.71 \\
\hline \multirow{2}{*}{ Convolvulaceae } & \multirow{2}{*}{ Ipomoea } & Ipomoea coptica Willd. & 1.28 & 0.74 & 1.77 & 5.17 & 2.04 & 3.87 \\
\hline & & Ipomoea sinuata Ort. & - & - & 3.18 & - & - & - \\
\hline
\end{tabular}


Table 3. Cont.

\begin{tabular}{|c|c|c|c|c|c|c|c|c|}
\hline Family & Genera & Species & \multicolumn{3}{|c|}{ BCC } & \multicolumn{3}{|c|}{ OCC } \\
\hline \multirow{3}{*}{ Fabaceae } & \multirow{2}{*}{ Indigofera } & Indigofera berhautiana JB. Gillett. & - & - & 1.06 & - & - & 1.66 \\
\hline & & Indigofera linifolia (Lf) Retz. & - & - & 1.06 & - & - & 2.21 \\
\hline & Alysicarpus & $\begin{array}{c}\text { Alysicarpus ovalifolius Schum.\& } \\
\text { Thonn. }\end{array}$ & 1.92 & 3.33 & 1.77 & - & - & 2.21 \\
\hline Amaryllidaceae & Pancratium & Pancratium trianthum Herb. & - & 1.48 & 3.18 & - & - & - \\
\hline Plantaginaceae & Scoparia & Scoparia dulcis L. & - & 3.70 & - & 5.17 & 0.68 & 1.10 \\
\hline Asteraceae & Sphaeranthus & Sphaeranthus senegalensis DC. & 7.05 & 4.44 & 1.77 & 2.59 & 5.44 & 3.87 \\
\hline Aizoaceae & Sesuvium & Sesuvium portulacastrum (L.) L. & 14.10 & 8.89 & 3.53 & 7.76 & 9.52 & 7.18 \\
\hline Acanthaceae & Hygrophila & Hygrophila senegalensis (Nees) T.A & 8.33 & 7.78 & 7.77 & 5.17 & 5.44 & 6.63 \\
\hline
\end{tabular}

The specific presence contribution reflects the participation of the species in the spatial occupation of the plantation. In 2016, the larger contribution towards spatial occupation below the Casuarina canopy was provided by the species Sesuvium portulacastrum (L.) L. (14.10\%), Philoxerus vermicularis (L.) Sm. (8.33\%), Hygrophila senegalensis (Nees) T. Anderson (8.33\%), and Sphaeranthus senegalensis DC. (7.05\%). Outside of the Casuarina canopy, Philoxerus vermicularis (17.24\%), Sesuvium portulacastrum (7.76\%), Spermacoce verticillata L. (6.03\%), and Amaranthus greacizans L. (6.03\%) occupied the greatest space. In 2017, below canopy domination, the species Sesuvium portulacastrum (L.) L. (8.89\%), Hygrophila senegalensis (7.78\%), Sphaeranthus senegalensis (4.44\%), Boerhavia repens L. (4.07\%), and Cyperus esculentus L. (4.07\%) were more significant, whereas outside the Casuarina canopy, Philoxerus vermicularis $(16.33 \%)$, Sesuvium portulacastrum (9.52\%), Melochia corchorifolia L. (5.44\%), and Sphaeranthus senegalensis (5.44\%) were more dominant. Similarly, in 2018, greater spatial occupation below the canopy was found in the species Philoxerus vermicularis (8.13\%), Hygrophila senegalensis $(7.77 \%)$, Corchorus tridens L. $(7.42 \%)$, and Sporobolus robustus Kunth. (7.07\%), whereas outside the canopy Philoxerus vermicularis $(12.71 \%)$, Sesuvium portulacastrum (7.18\%), Hygrophila senegalensis (6.63\%), and Digitaria horizontalis Willd. (6.08\%) were more prevalant (Table 4$)$.

Table 4. Inter-annual variation of coverage, specific richness, and diversity index below the Casuarina canopy (BCC) and outside the Casuarina canopy (OCC). Lower-case letters $(\mathrm{a}-\mathrm{c})$ indicate significant differences according to the two-way ANOVA between conditions and years.

\begin{tabular}{ccccccc}
\hline & \multicolumn{3}{c}{ BCC } & \multicolumn{3}{c}{ OCC } \\
\hline Years & 2016 & 2017 & 2018 & 2016 & 2017 & 2018 \\
\hline Coverage (\%) & $48.28 \mathrm{~b}$ & $67.48 \mathrm{a}$ & $71.95 \mathrm{a}$ & $37.57 \mathrm{~b}$ & $43.26 \mathrm{~b}$ & $45.03 \mathrm{~b}$ \\
\hline Specific richness & $24 \mathrm{~b}$ & $29 \mathrm{ab}$ & $33 \mathrm{a}$ & $21 \mathrm{~b}$ & $22 \mathrm{~b}$ & $24 \mathrm{~b}$ \\
\hline Shannon index & $1.9 \mathrm{~b}$ & $2.26 \mathrm{a}$ & $2.39 \mathrm{a}$ & $1.67 \mathrm{c}$ & $1.76 \mathrm{c}$ & $2.05 \mathrm{~b}$ \\
\hline Evenness & 0.41 & 0.46 & 0.47 & 0.38 & 0.39 & 0.44 \\
\hline
\end{tabular}

\subsection{Coverage, Specific Richness, and Diversity Index below and outside the Casuarina Canopy}

The coverage of the herbaceous vegetation below the Casuarina canopy was $48.28 \%$ in $2016,67.48 \%$ in 2017 , and $71.95 \%$ in 2018 . Outside the canopy vegetation coverage was of $37.57 \%$ in $2016,43.26 \%$ in 2017, and $45.03 \%$ in 2018.

Below the Casuarina canopy, the specific richness was 24, 29, and 33 species in 2016, 2017, and 2018, respectively. Outside of the canopy, the specific richness was 21, 22, and 24 species in 2016, 2017, and 2018, respectively (Table 5). In 2016, the below-canopy Shannon index ( $\left.\mathrm{H}^{\prime}\right)$ and evenness 
(E) were of 1.9 and 0.41 , respectively. In 2017, an increase of Shannon index and evenness of 2.26 and 0.46, respectively, was observed, whereas outside of the Casuarina canopy, they were 1.67 and 0.38 , respectively. In 2018, a further increase of Shannon index and evenness was also observed (2.39 and 0.47 ) with the outside canopy indices being 2.05 and 0.44 , respectively.

Table 5. Specific contribution dry biomass (Csib) below (BCC) and outside the Casuarina canopy (OCC).

\begin{tabular}{|c|c|c|c|c|c|c|}
\hline \multirow[b]{3}{*}{ Species } & \multicolumn{3}{|c|}{ BCC } & \multicolumn{3}{|c|}{ OCC } \\
\hline & \multicolumn{3}{|c|}{ Csib } & \multicolumn{3}{|c|}{ Csib } \\
\hline & 2016 & 2017 & 2018 & 2016 & 2017 & 2018 \\
\hline Dactylotenium aegyptium (L.) Willd & 3.12 & 1.44 & 1.97 & 2.46 & 2.56 & 1.90 \\
\hline Schizachirium compressa (K. Schum.) Stapf & 1.78 & 1.65 & 3.63 & - & - & - \\
\hline Schisachyrium rupestre (Stapf) Stapf & - & - & - & 1.87 & 1.21 & 0.56 \\
\hline Chloris prieuriiKunt & 10.79 & 8.21 & 1.14 & 5.32 & 4.56 & 4.64 \\
\hline Chloris barbata (L.) Sw. & - & 10.29 & 5.43 & - & - & - \\
\hline Pennisetum polystachion (L.) Schul. & - & 2.30 & 5.99 & 3.97 & 4.75 & 3.08 \\
\hline Eragrostis tenella (L.) Beauv. & 4.24 & 2.01 & 3.41 & - & - & - \\
\hline Eragrostis tremula Hochst. Ex Steud. & 5.53 & 2.73 & 2.68 & 3.77 & 2.41 & 5.84 \\
\hline Eragrostis aspera (Jacq.) Nees. & 3.48 & 4.44 & 3.30 & - & - & - \\
\hline Paspalum vaginatum (L.) & 1.22 & 5.64 & 2.79 & - & - & - \\
\hline Aristida funiculata Trin. \& Rupr. & - & 2.19 & 1.83 & 5.24 & 3.05 & 3.27 \\
\hline Aristida mutabilis Trin. \& Rupr. & - & 1.22 & 4.04 & - & - & - \\
\hline Digitaria horizontalis Willd. & 2.59 & 2.48 & 1.43 & 3.10 & 3.84 & 3.70 \\
\hline Brachiaria lata (Schumach.) C.E. Hubb. & - & 2.80 & 2.38 & - & - & - \\
\hline Sporobolus robustus Kunth. & 12.97 & 4.40 & 7.80 & 4.45 & 8.07 & 4.21 \\
\hline Hibiscus rostellatus (Guill. \& Perr.) & 2.28 & 0.61 & 4.65 & - & - & - \\
\hline Hibiscus asper Hook. & - & - & 0.83 & - & - & - \\
\hline Corchorus tridens L. & 0.58 & 1.13 & 2.88 & 2.82 & 3.17 & - \\
\hline Sida alba L. & 0.89 & - & - & 4.17 & 3.35 & 4.96 \\
\hline Fuirena ciliaris (L.) Roxb. & 0.53 & - & - & 3.34 & 3.77 & 3.10 \\
\hline Cyperus esculentus L. & 2.01 & 2.16 & 2.39 & - & 2.68 & 3.38 \\
\hline Cyperus bulbosus Vahl. & 2.23 & 1.72 & 2.65 & 2.30 & 3.09 & 1.85 \\
\hline Amaranthus greacizans L. & 0.94 & 1.69 & 1.20 & 3.89 & 3.77 & 2.68 \\
\hline Philoxerus vermicularis (L.) Sm. & 9.31 & 9.59 & 4.36 & 8.42 & 8.82 & 5.46 \\
\hline Alysicarpus ovalifolius Schum. \& Thonn. & 1.35 & 0.74 & 0.43 & - & - & 1.42 \\
\hline Pancratium trianthum Herb. & - & 2.17 & 3.80 & - & - & - \\
\hline Boerhavia repens $\mathrm{L}$. & 0.91 & 0.43 & - & 1.43 & 2.15 & 0.91 \\
\hline Scoparia dulcis L. & - & 1.37 & 0.97 & 3.97 & 4.67 & 3.91 \\
\hline Sphaeranthus senegalensis DC. & 2.18 & 1.44 & - & 3.02 & 2.26 & 3.11 \\
\hline Sesuvium portulacastrum (L.) L. & 13.35 & 12.22 & 6.57 & 16.44 & 11.99 & 7.61 \\
\hline Hygrophila senegalensis (Nees)T. Anderson & 14.67 & 9.18 & 6.54 & 12.91 & 10.06 & 7.88 \\
\hline Spermacoce verticillata $\mathrm{L}$. & 1.24 & 2.23 & 4.01 & 2.66 & 2.00 & 2.20 \\
\hline Ipomoea coptica Willd. & 1.80 & 1.51 & 2.35 & 4.45 & 7.76 & 2.98 \\
\hline Ipomoea sinuata Ort. & - & - & 2.39 & - & - & - \\
\hline Indigofera berhautiana JB. Gillett. & - & - & 1.44 & - & - & 5.01 \\
\hline Indigofera linifolia (Lf) Retz. & - & - & 1.23 & - & - & 5.01 \\
\hline Melochia corchorifolia L. & - & - & 1.10 & - & - & - \\
\hline
\end{tabular}


The Jaccard similarity index between below and outside the Casuarina canopy surveys was 0.69 in 2016. A decrease of this index to 0.59 and 0.54 in 2017 and 2018, respectively, was observed (Figure 3a). Below the Casuarina canopy, the Jaccard similarity index varied from 0.62 between 2016 and 2017, to 0.55 between 2016 and 2018 and 0.82 between 2017 and 2018 (Figure 3b).

Jaccard similarity index

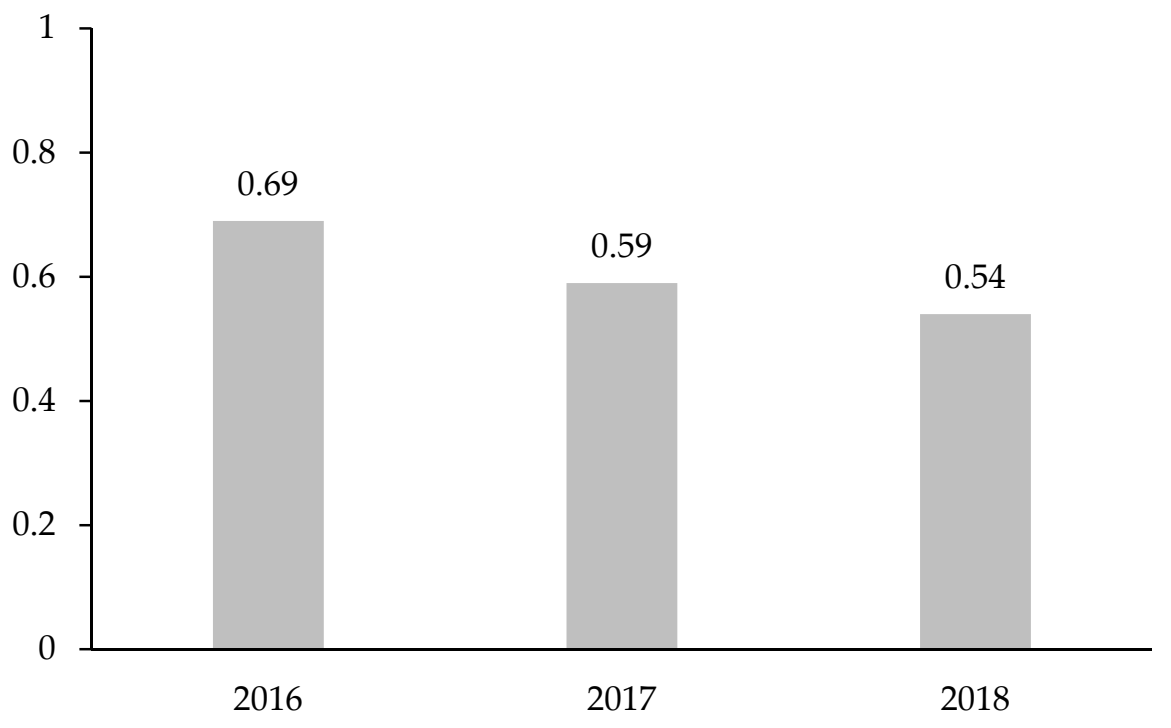

Jaccard similarity index

(b)

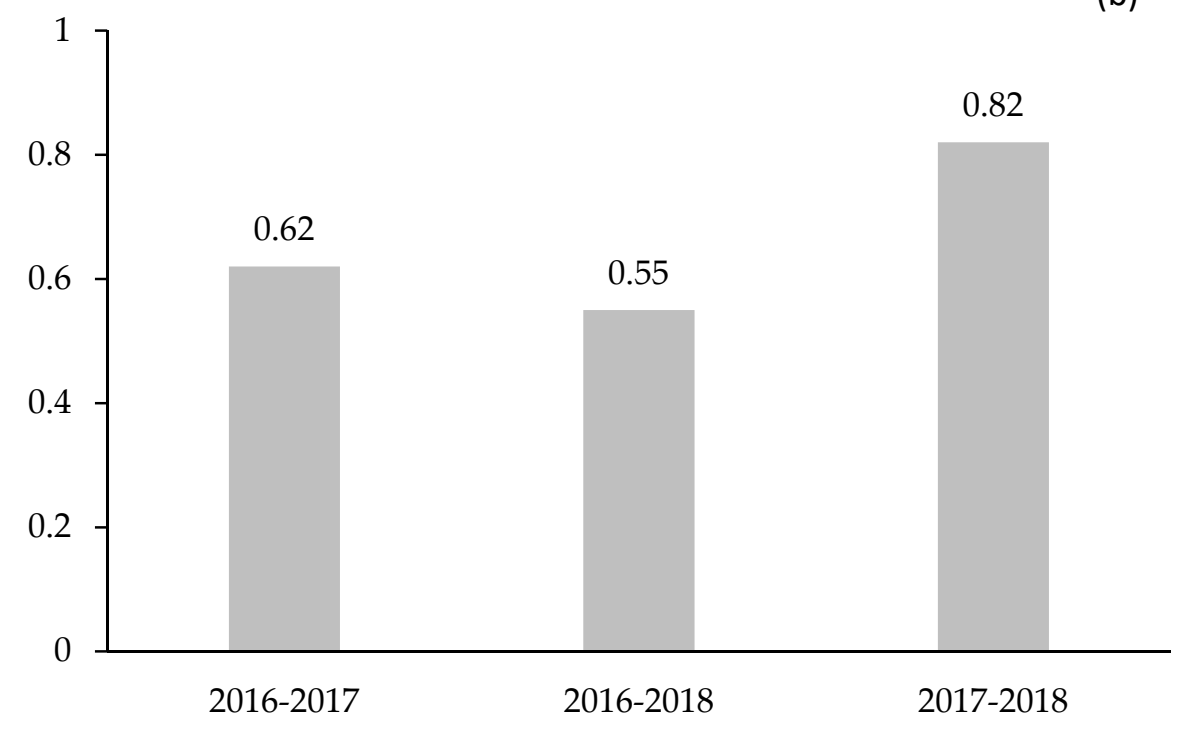

Figure 3. Jaccard similarity index (a) between below and outside the Casuarina canopy surveys in 2016, 2017, and 2018 (b) Jaccard similarity index below Casuarina canopy between the years 2016-2017, 2016-2018, and 2017-2018.

NMDS was used to explore variation among species below and outside Casuarina canopy as a function of the years. Floristic differences were observed between the surveys conducted on below-canopy species in 2017-2018 as well as outside Casuarina canopy in 2016-2017 and 2018 (Figure 4). 


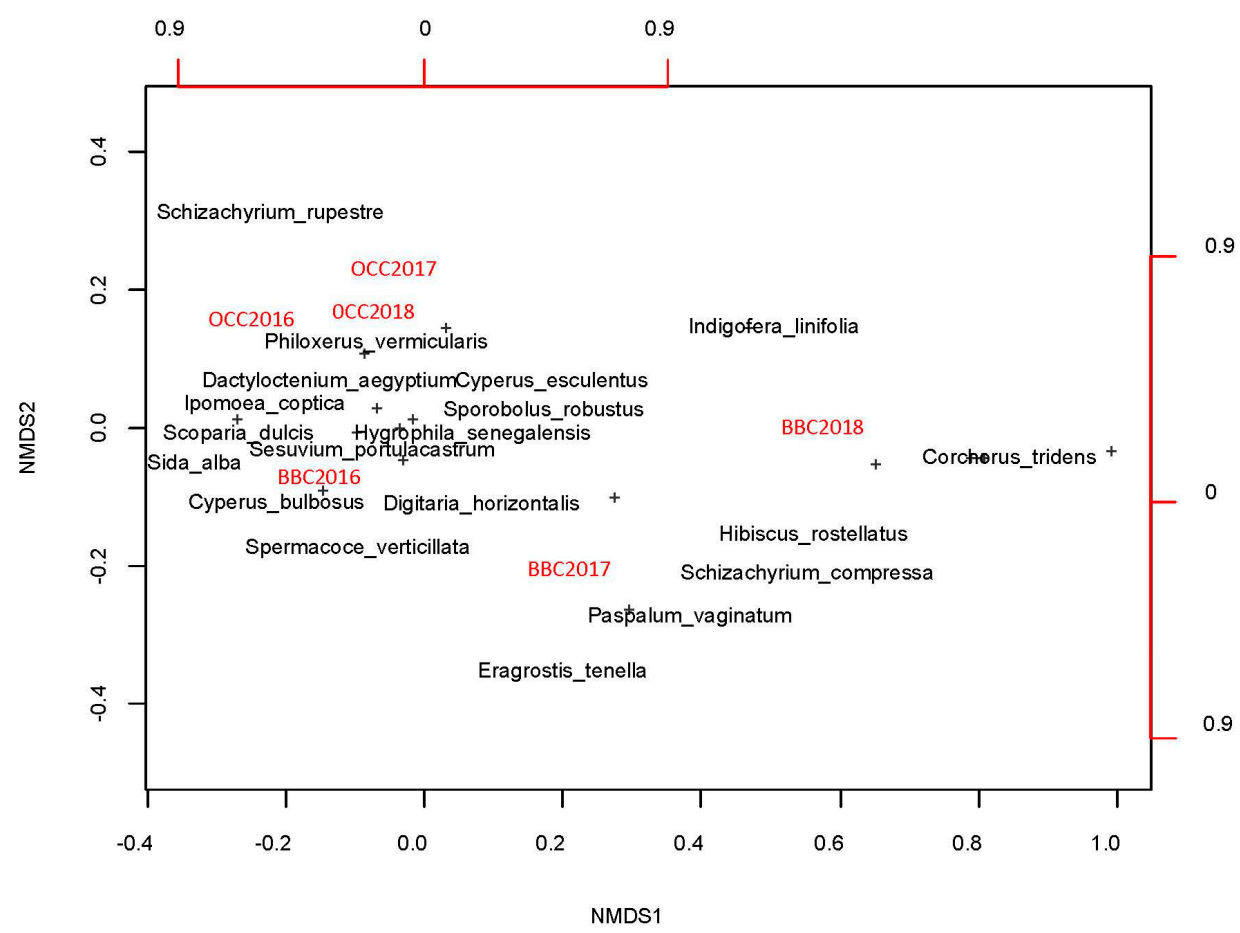

Figure 4. Non-metric multidimensional scaling (NMDS) ordination of species composition below Casuarina canopy (BBC) and outside Casuarina canopy (OCC) in 2016, 2017, and 2018.

\subsection{Effect of Casuarina Species on Herbaceous Biomass in Saline Conditions}

The results obtained showed a significant difference in biomass production below the Casuarina canopy in 2017 and 2018 ( $0.60 \pm 0.18$ t.MS/ha and $0.78 \pm 0.14$ t.MS/ha, respectively) compared to 2016 $(0.39 \pm 0.17$ t.MS/ha). There is no significant difference in the biomass production outside the Casuarina canopy between 2016, 2017, and 2018 (Figure 5). Below the Casuarina canopy, biomass was significantly higher compared to outside the Casuarina canopy biomass in 2017 and 2018.

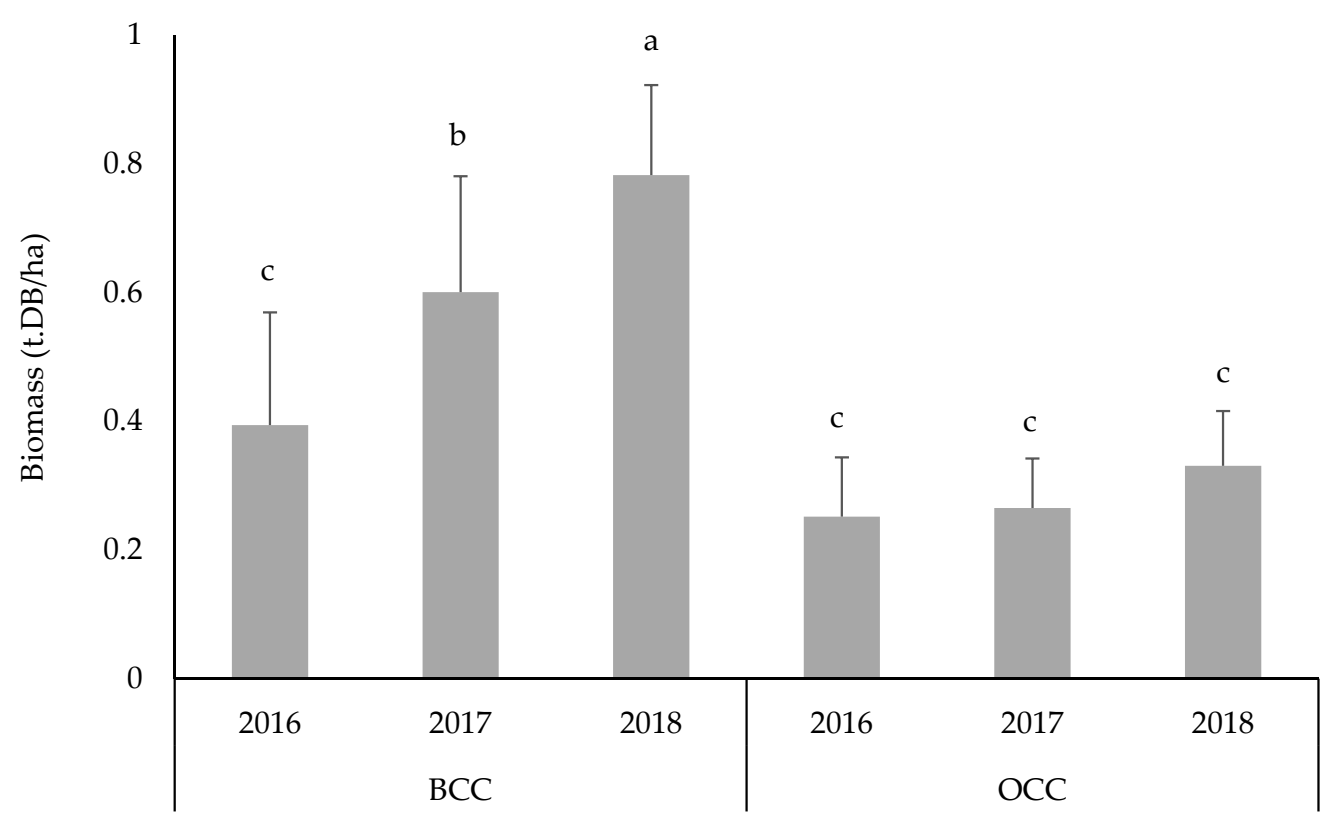

Figure 5. Inter-annual variation of biomass (BCC) below the Casuarina canopy (OCC) and outside the Casuarina canopy. Lower-case letters (a-c) indicate significant differences between the years 2016, 2017, and 2018 for each condition. 


\subsection{Specific Contribution of Dry Biomass below and outside the Casuarina Canopy}

In 2016, the predominant species in terms of dry biomass production were Hygrophila senegalensis (14.64\%), Sesuvium portulacastrum (13.35\%), and Sporobolus robustus (12.97\%). Outside the Casuarina canopy, the largest contributions towards dry biomass came from Sesuvium portulacastrum $(16.44 \%)$ and Hygrophila senegalensis (12.91\%). In 2017, the greatest biomass production was provided by below-canopy species Sesuvium portulacastrum (12.22\%), Chloris barbata (10.29\%), and Hygrophila senegalensis $(9.18 \%)$. Outside the Casuarina canopy, the species Sesuvium portulacastrum $(11.99 \%)$ and Hygrophila senegalensis (10.06\%) provided the greatest dry biomass. By 2018, the largest biomass producers below the Casuarina canopy were Sporobolus robustus (7.80\%), Sesuvium portulacastrum (6.57\%), Hygrophila senegalensis (6.54\%), and Pennisetum polystatachion (5.99\%). Outside of the Casuarina canopy, biomass was greatest from Sesuvium portulacastrum (7.88), Hygrophila senegalensis (7.61\%), and Eragrostis tremula (5.84\%) (Table 5).

\section{Discussion}

Data provided in this study confirm that both C. glauca and C. equisetifolia can grow in saline soils. A soil is considered to be salty if it contains a minimum of $40 \mathrm{mM} \mathrm{NaCl}$ [28]. However, in our study area, the salt concentration of the soil can be $500 \mathrm{mM}$ or higher during the dry season. It has been shown that Casuarina glauca, Casuarina obesa, and Casuarina equisetifolia will survive up to $500 \mathrm{mM} \mathrm{NaCl}$ if grown in a hydroponic medium supplemented with adequate nitrogen [19]. However, under field conditions, other factors such as drought, temperature, and the presence of other toxic ions, such as $\mathrm{Mg}^{2+}, \mathrm{SO}_{4}{ }^{2-}, \mathrm{HCO}^{3-}$, and $\mathrm{CO}_{3}{ }^{2-}$, can have negative effects on plant growth and survival [1]. In our study, the highest survival rates in both C. glauca and C. equisetifolia occurred in plants that had been inoculated with either Frankia or and co-inoculated with Frankia and Rf. These results show the importance of inoculation with AMF ( $R$. fasciculatus) and/or nitrogen-fixing bacteria (Frankia) in improving Casuarina salt tolerance, especially in reducing post-transplant stress $[7,17]$ and wood production. We did note, however, a decline in survival rate of $C$. glauca in the third year of this study. This could be linked to competition between the inoculum with native strains [29]. However, significant plant mortality could be related to the extreme sodium levels in the dry periods and periodic waterlogging observed at certain points in the plantation.

The effects of co-inoculation (AMF/Frankia) on plant growth under salt stress conditions under field conditions are poorly documented. However, similar results have been obtained under greenhouse conditions by the work of Soliman et al. [30], Ashrafi et al. [31], and Ren et al. [32] on the positive effect of co-inoculation with nitrogen-fixing bacteria and arbuscular mycorrhizal fungi on the development of Acacia saligna, Medicago sativa, and Sesbania cannabina plants at 250, 180, and $200 \mathrm{mM}$, respectively.

The increased height of plants co-inoculated with Frankia and arbuscular mycorrhizal fungi (AMF) could be explained by their facilitation in absorption of and control in levels of mineral elements. For example, selective absorption of ions, such as phosphorus, nitrogen, and magnesium and reduced absorption of $\mathrm{Na}^{+}$ions [33]. This selective ionic uptake reduces ionic imbalances and the antagonistic effects between ions [32] that often lead to nutritional problems caused by the saline conditions exacerbated by water deficit stress.

In terms of the effect of C.glauca and C. equisetifolia on biodiversity of herbaceous vegetation in the area, this was evident only four years (2017) after planting. There were no significant differences between the two Cassurina species with respect to the biodiversity in this vegetation (Table A1). The Shannon diversity indexes were 1.9, 2.26, and 2.39 bits in 2016, 2017, and 2018, respectively, below the Casuarina canopy and 1.67, 1.76, and 2.05 bits outside the Casuarina canopy. This inter-annual increase of the diversity could be explained by the presence of the tree, which gradually improves soil porosity, promotes good drainage [34], maintains better activity by the microbial community, and consequently increases the diversity of herbaceous vegetation. However, there is little data on the effect of trees on the diversity of herbaceous vegetation in saline conditions. Studies by Trites and Baley [35] showed a decrease in the richness of the plant community as a function of the salinity gradient and $\mathrm{pH}$. 
Our opposite results could be related to the heterogeneity of the electrical conductivity in the soil due to periodic waterlogging at some points of the plantation during rainy season.

Phosphorus $(\mathrm{P})$ and nitrogen $(\mathrm{N})$ are considered the most important elements in plant growth, and paucity thereof is has been suggested to be the greatest limitation to plant growth in most ecosystems [36]. Here, we show that the presence of Casuarina species results in increased phosphorus, nitrogen, and carbon contents (Table 1). These results can be explained by the decomposition of Casuarina litter that can improve soil fertility. The decomposition of Casuarina litter under semi-arid conditions results in the release of many nutrients in the following order: $\mathrm{Ca}>\mathrm{N}>\mathrm{K}>\mathrm{Mg}>\mathrm{Na}>\mathrm{P}>$ $\mathrm{Fe}>\mathrm{Zn}>\mathrm{Cu}>\mathrm{Cr}$ [37]. The Work of Hata et al. [38] suggests that decomposition of C. equisetifolia litter can alter the total $\mathrm{N}$ and $\mathrm{N}$ cycle in invaded forest ecosystems.

A decrease in the Jaccard similarity index between the populations below and outside Casuarina canopy over the successive years of this study (Figure 3) suggests differences in biological diversity among the environments. The NMDS analysis also showed a difference in the floristic composition between the surveys below Casuarina canopy in 2017-2018 and outside Casuarina canopy in 2016-2017 and 2018. This difference could be related to the beneficial effects of Casuarina species, which improve soil fertility through nitrogen inputs [39] and create a microclimate favorable to the establishment of herbaceous vegetation. These results can also be explained by the inter-annual presence of perennial herbaceous plants capable of improving the physicochemical properties of the soil.

The beneficial effect of herbaceous plants on decreasing soil salinity has been observed by several authors $[40,41]$. These herbaceous plants can improve leaching and interactions between soil chemical properties supposedly restoring soil fertility. Our results confirm this proposal with significant increases in carbon, nitrogen, and phosphorus levels occurring 3 years after planting.

A better herbaceous vegetation coverage was obtained below the Casuarina canopy $(67.48 \%$ and $71.95 \%$ in 2017 and 2018, respectively) compared to that outside the canopy ( $43.26 \%$ and 45.03 in 2017 and 2018, respectively). This positive effect could be due to the presence of certain herbaceous plants capable of symbiosis with nitrogen-fixing endophytes. This has been reported for Sporobulus robustus with Rhizobium bacteria [15] and Leptochloa fusca with Azoarcus bacteria [42]. In turn, these can be considered pioneering species that improve soil fertility and encourage the establishment and growth of other herbaceous species.

The species that contributed most to the coverage of the plantation were S. portulacastrum and S. robustus, while outside the Casuarina canopy, S. portulacastrum and Philoxerus vermicularis were dominant. Ravindran et al. [43] have shown that S. portulacastrum and S. maritima accumulate salt in their tissues with a corresponding reduction thereof in the soil. It is estimated that these two halophytes could remove 474 and $504 \mathrm{~kg}$ of $\mathrm{NaCl}$, respectively, per ha over a 4 month period. Our results similarly showed a decrease in soil salt concentration 3 years after establishment of the plantation. This in turn suggests that at least some of these herbaceous plants are able to reduce $\mathrm{NaCl}$ in the environment and make conditions more favorable for growth of Casuarina species by inter alia improving soil water availability. Grouzis and Akpo [44] have shown that in arid environments, the presence of trees improves biomass of other plants in their vicinity. The same could be true under saline environments. We have shown an increase in herbaceous biomass in association with the presence of Casuarina species, which in turn could promote the incorporation of organic biomass and facilitate salt leaching, especially $\mathrm{Na}^{+}$by rain.

\section{Conclusions}

C. equisetifolia and C. glauca species can be grown in saline conditions, albeit with some limitations related to the increase in salt concentration in the dry season and waterlogging conditions in the rainy seasons. Inoculation with AMF and Frankia increased plant growth during 3 years of planting. The Casuarina plantation had a positive effect on the diversity of herbaceous vegetation in salty conditions after 5 years of planting. Salt-grasses that have a greater contribution to coverage can be used to improve soil drainage and reduce salt concentration in future rehabilitation programs. 
Author Contributions: P.I.D., D.N. and N.D. did the experimental work and analysis thereof and wrote the manuscript; V.H., D.F., D.D., M.N., L.L. A.C., and S.S. contributed in designing, supervision and interpretation of the results. J.M.F. edited the final manuscript. All authors have read and agreed to the published version of the manuscript.

Funding: This work was supported by the International Foundation for Sciences (IFS, no. AD/22680), the Academy of Sciences for the Developing World (TWAS, no. 11-214 RG/BIO/AF/AC I), The "Fonds d'Impulsion de la Recherche Scientifique et Technique" (FIRST) of the Ministry of Higher Education and Research of Senegal.

Acknowledgments: The "Laboratoire Mixte International Adaptation des Plantes et microorganismes associés aux Stress Environnementaux" (LAPSE). We thank Chris McMillan (International Programs Coordinator Jesuit Mission) for his participation in English correction and Amadou Mbarrick Diarra for the design of the area map. Our thanks to the whole village of Palmarin, especially Camille and Gilbert for their help in maintaining the plantation.

Conflicts of Interest: The authors declare that they have no conflict of interest.

\section{Appendix A}

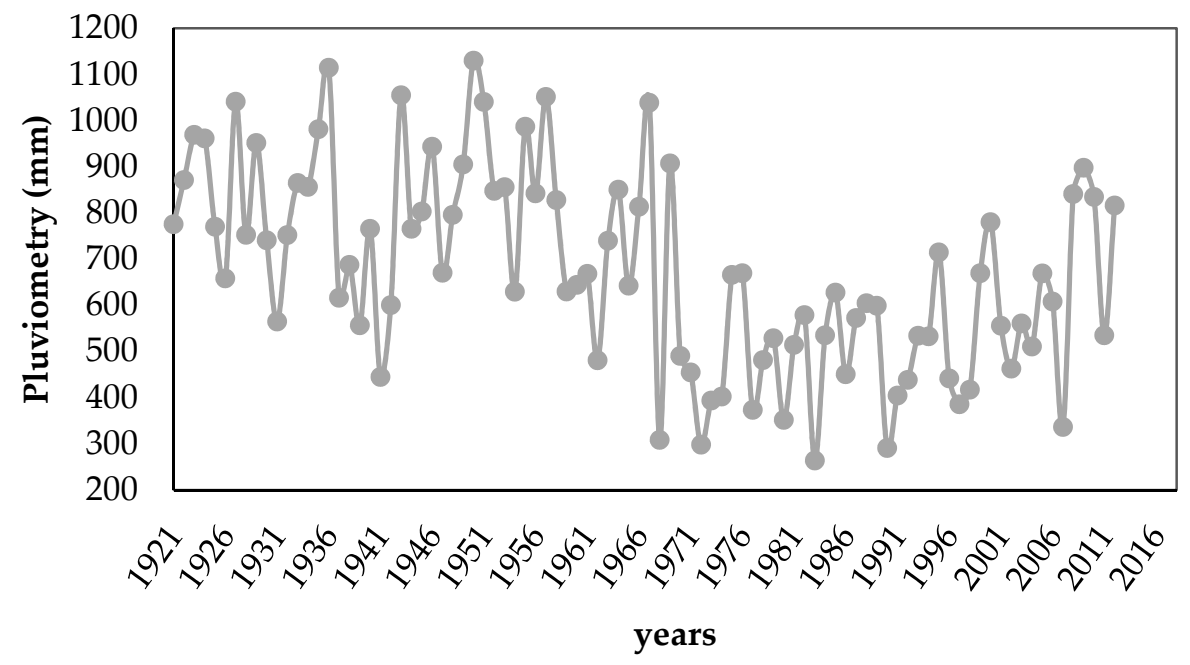

Figure A1. Rainfall data from the Fatick region (Senegal) over the period 1921-2016.

Table A1. Two-way ANOVA analysis of plant species, inoculation, and their interactions with height, collar diameter, survival rate, specific contribution presence, and dry biomass.

\begin{tabular}{cccccc}
\hline & Height & Collar Diameter & Survival Rate & Specific Contribution Presence & Dry Biomass \\
\hline Species & $* *$ & $\mathrm{~ns}$ & $*$ & $\mathrm{~ns}$ & $\mathrm{~ns}$ \\
Inoculation & $* * *$ & $\mathrm{~ns}$ & $* *$ & $\mathrm{~ns}$ & $\mathrm{~ns}$ \\
Species $\times$ Inoculation & $\mathrm{ns}$ & $\mathrm{ns}$ & $\mathrm{ns}$ & $\mathrm{ns}$ & $\mathrm{ns}$ \\
\hline
\end{tabular}

ns, no significant difference; ${ }^{* * *}$ and ${ }^{* * *}$ indicate significant difference at $p<0.1,0.05,0.01$, and 0.001 , respectively.

\section{References}

1. Qadir, M.; Schubert, S. Degradation processes and nutrient constraints in sodic soils. Land Degrad. Dev. 2002, 13, 275-294. [CrossRef]

2. Diadhiou, Y.B.; Ndour, A.; Niang, I.; Niang-Fall, A. Étude comparative de l'évolution du trait de côte sur deux flèches sableuses de la Petite Côte (Sénégal): Cas de Joal et de Djiffère. Norois 2016, 25-42. [CrossRef]

3. Agence National de la Statistique et de la Démographie (ANSD). Recensement Générale de la Population et de l'Habitat (RGPH). 1988. Available online: http://www.ansd.sn/ressources/rapports/Rapport_RGPH_88.pdf (accessed on 7 February 2020).

4. Agence National de la Statistique et de la Démographie (ANSD). Recensement Général de la Population et de l'Habitat, de l'Agriculture et de l'Elevage (RGPHAE). 2013. Available online: http://www.ansd.sn/ ressources/rapports/Rapport-definitif-RGPHAE2013.pdf (accessed on 7 February 2020). 
5. Bleibaum, F. Case Study Senegal: Environmental Degradation and Forced Migration. In Environment, Forced Migration and Social Vulnerability; Afifi, T., Jäger, J., Eds.; Springer: Berlin/Heidelberg, Germany, 2010. [CrossRef]

6. Potgieter, L.J.; Richardson, D.M.; Wilson, J.R.U. Casuarina cunninghamiana in the Western Cape, South Africa: Determinants of naturalisation and invasion, and options for management. South Afr. J. Bot. 2014, 92, 134-146. [CrossRef]

7. Djighaly, P.I.; Diagne, N.; Ngom, M.; Ngom, D.; Hocher, V.; Fall, D.; Diouf, D.; Laplaze, L.; Svistoonoff, S.; Champion, A. Selection of arbuscular mycorrhizal fungal strains to improve Casuarina equisetifolia L. and Casuarina glauca Sieb. tolerance to salinity. Ann. For. Sci. 2018, 75, 72. [CrossRef]

8. Sayed, W.F. Improving Casuarina growth and symbiosis with Frankia under different soil and environmental conditions-Review. Folia Microbiol. 2011, 56, 1-9. [CrossRef]

9. Diagne, N.; Diouf, D.; Svistoonoff, S.; Kane, A.; Noba, K.; Franche, C.; Bogusz, D.; Duponnois, R. Casuarina in Africa: Distribution, role and importance of arbuscular mycorrhizal, ectomycorrhizal fungi and Frankia on plant development. J. Environ. Manag. 2013, 128, 204-209. [CrossRef]

10. Duro, N.; Batista-Santos, P.; da Costa, M.; Maia, R.; Castro, I.V.; Ramos, M.; Ramalho, J.C.; Pawlowski, K.; Máguas, C.; Ribeiro-Barros, A. The impact of salinity on the symbiosis between Casuarina glauca Sieb. ex Spreng, and $\mathrm{N}_{2}$-fixing Frankia bacteria based on the analysis of Nitrogen and Carbon metabolism. Plant Soil 2016, 398, 327-337. [CrossRef]

11. Hanin, M.; Ebel, C.; Ngom, M.; Laplaze, L.; Masmoudi, K. New Insights on Plant Salt Tolerance Mechanisms and Their Potential Use for Breeding. Front. Plant Sci. 2016, 7, 708. [CrossRef]

12. Abeer, H.; Abd_Allah, E.F.; Alqarawi, A.; Egamberdieva, D. Induction of salt stress tolerance in cowpea [Vigna unguiculata (L.) Walp.] by arbuscular mycorrhizal fungi. Legum. Res. Int. J. 2015, 38, 579-588. [CrossRef]

13. Krishnamoorthy, R.; Kim, K.; Subramanian, P.; Senthilkumar, M.; Anandham, R.; Sa, T.-M. Arbuscular mycorrhizal fungi and associated bacteria isolated from salt-affected soil enhances the tolerance of maize to salinity in coastal reclamation soil. Agric. Ecosyst. Environ. 2016, 231, 233-239. [CrossRef]

14. Zhong, C.; Zhang, Y.; Chen, Y.; Jiang, Q.; Chen, Z.; Liang, J.-F.; Pinyopusarerk, K.; Franche, C.; Bogusz, D. Casuarina research and applications in China. Symbiosis 2009, 50, 107-114. [CrossRef]

15. Fall, F.; Le Roux, C.; Bâ, A.M.; Fall, D.; Bakhoum, N.; Faye, M.N.; Kane, A.; Ndoye, I.; Diouf, D. The rhizosphere of the halophytic grass Sporobolus robustus Kunth hosts rhizobium genospecies that are efficient on Prosopis juliflora (Sw.) DC and Vachellia seyal (Del.) P.J.H. Hurter seedlings. Syst. Appl. Microbiol. 2019, 42, 232-239. [CrossRef] [PubMed]

16. Fierer, N.; Bradford, M.A.; Jackson, R.B. toward an ecological classification of soil bacteria. Ecology 2007, 88, 1354-1364. [CrossRef] [PubMed]

17. Goldfarb, K.C.; Karaoz, U.; Hanson, C.A.; Santee, C.A.; Bradford, M.A.; Treseder, K.; Wallenstein, M.D.; Brodie, E.L. Differential Growth Responses of Soil Bacterial Taxa to Carbon Substrates of Varying Chemical Recalcitrance. Front. Microbiol. 2011, 2, 94. [CrossRef] [PubMed]

18. Diem, H.G.; Dommergues, Y. The isolation of Frankia from nodules of Casuarina. Can. J. Bot. 1983, 61, 2822-2825. [CrossRef]

19. Ngom, M.; Gray, K.; Diagne, N.; Oshone, R.; Fardoux, J.; Gherbi, H.; Hocher, V.; Svistoonoff, S.; Laplaze, L.; Tisa, L.S.; et al. Symbiotic Performance of Diverse Frankia Strains on Salt-Stressed Casuarina glauca and Casuarina equisetifolia Plants. Front. Plant Sci. 2016, 7, 1. [CrossRef]

20. Braun-Blanquet, J. Pflanzensoziologie: Grundzüge der Vegetationskunde. Mit 168 Abb. Biologische Studienbücher (Geschlossen); Springer: Berlin/Heidelberg, Germany, 1928; ISBN 978-3-662-02056-2.

21. Gillet, F. La Phytosociologie Synusiale Intégrée. Guide Méthodologique; Université de Neuchâtel, Institut de Botanique: Neuchâtel, Switzerland, 2000; 68p.

22. Berhaut, J. La Flore illustrée du Sénégal. Préf. de L. Sédar Senghor. J. D'agriculture Traditionnelle Botanique Appliquée 1974, 21, 269-270.

23. Lebrun, J.-P.; Stork, A.L. Enumération des Plantes à fleurs d'Afrique Tropicale-Volume 1: Généralités et Annonaceae à Pandaceae; Conservatoire et Jardin botaniques de la Ville de Genève: Geneva, Switzerland, 1991; ISBN 978-2-8277-0108-7.

24. Lebrun, J.-P.; Stork, A.L. Enumération des Plantes à Fleurs d'Afrique Tropicale. Volume II. Chrysobalanaceae à Apiaceae; Conservatoire et Jardin botaniques de la Ville de Genève: Geneva, Switzerland, 1992; ISBN 978-2-8277-0109-4. 
25. Rougerie, G.S. Frontier et D. Pichod-Viale, Écosystèmes: Structure, fonctionnement, évolution. Annales Géographie 1992, 101, 343-344.

26. Daget, P.; Poissonet, J. Une méthode d'analyse phytosociologique des prairies. Critères d'application. Ann. Agron. 1972, 22, 5-41.

27. Rusch, G.; Armas, C.; Diouf, M.; Zapata, P.; Fall, D.; Casanoves, F.; Diémé, J.; Ibrahim, M.; Declerck, F.; Pugnaire, F. The importance of environmental gradients and tree functional attributes on tree-understory interactions in seasonally dry tropical agroforestry systems. In Proceedings of the Final Conference: “The Role of Functional Diversity for Ecosystem Services in Multi-Functional Agroforestry", Trondheim, Norway, 23-25 May 2013.

28. Munns, R.; Tester, M. Mechanisms of Salinity Tolerance. Annu. Rev. Plant Boil. 2008, 59, 651-681. [CrossRef]

29. Engelmoer, D.J.P.; Behm, J.E.; Kiers, E.T. Intense competition between arbuscular mycorrhizal mutualists in anin vitroroot microbiome negatively affects total fungal abundance. Mol. Ecol. 2013, 23, 1584-1593. [CrossRef] [PubMed]

30. Soliman, A.S.; Shanan, N.T.; Massoud, O.N.; Swelim, D.M. Improving salinity tolerance of Acacia saligna (Labill.) plant by arbuscular mycorrhizal fungi and Rhizobium inoculation. Afr. J. Biotechnol. 2012, 11, 1259-1266. [CrossRef]

31. Ashrafi, E.; Zahedi, M.; Razmjoo, J. Co-inoculations of arbuscular mycorrhizal fungi and rhizobia under salinity in alfalfa. Soil Sci. Plant Nutr. 2014, 60, 619-629. [CrossRef]

32. Ren, C.-G.; Bai, Y.-J.; Kong, C.-C.; Bian, B.; Xie, Z. Synergistic Interactions Between Salt-tolerant Rhizobia and Arbuscular Mycorrhizal Fungi on Salinity Tolerance of Sesbania cannabina Plants. J. Plant Growth Regul. 2016, 35, 1098-1107. [CrossRef]

33. Bar, Y.; Apelbaum, A.; Kafkafi, U.; Goren, R. Relationship between chloride and nitrate and its effect on growth and mineral composition of avocado and citrus plants. J. Plant Nutr. 1997, 20, 715-731. [CrossRef]

34. Mishra, A.; Sharma, S.D.; Khan, G.H. Rehabilitation of degraded sodic lands during a decade of Dalbergia sissoo plantation in Sultanpur District of Uttar Pradesh, India. Land Degrad. Dev. 2002, 13, 375-386. [CrossRef]

35. Trites, M.; Bayley, S.E. Vegetation communities in continental boreal wetlands along a salinity gradient: Implications for oil sands mining reclamation. Aquat. Bot. 2009, 91, 27-39. [CrossRef]

36. Ågren, G.I.; Wetterstedt, J.Å.M.; Billberger, M.F.K. Nutrient limitation on terrestrial plant growth-Modeling the interaction between nitrogen and phosphorus. New Phytol. 2012, 194, 953-960. [CrossRef]

37. Uma, M.; Saravanan, T.; Rajendran, K. Growth, litterfall and litter decomposition of Casuarina equisetifolia in a semiarid zone. J. Trop. For. Sci. 2014, 26, 125-133.

38. Hata, K.; Kato, H.; Kachi, N. Leaf litter of the invasive Casuarina equisetifolia decomposes at the same rate as that of native woody species on oceanic islands but releases more nitrogen. Weed Res. 2012, 52, 542-550. [CrossRef]

39. Diagne, N.; Djighaly, P.; Ngom, M.; Prodjinoto, H.; Ngom, D.; Hocher, V.; Fall, D.; Diouf, D.; Nambiar-Veetil, M.; Sy, M.; et al. Rehabilitation of Saline Lands Using Selected Salt-Tolerant Casuarina-Microorganisms Combinations. In Proceedings of the 5th International Casuarina Meeting, Chennai, India, 3-7 February 2014.

40. Dagar, J.C.; Minhas, P. (Eds.) Agroforestry for the Management of Waterlogged Saline Soils and Poor-Quality Waters. Advances in Agroforestry; Springer: Dordrecht, The Netherlands, 2016; ISBN 978-81-322-2657-4. [CrossRef]

41. Akhter, J.; Mahmood, K.; Malik, K.; Ahmed, S.; Murray, R. Amelioration of a saline sodic soil through cultivation of a salt-tolerant grass Leptochloa fusca. Environ. Conserv. 2003, 30, 168-174. [CrossRef]

42. Malik, K.A.; Bilal, R.; Mehnaz, S.; Rasul, G.; Mirza, M.; Ali, S. Association of nitrogen-fixing, plant-growth-promoting rhizobacteria (PGPR) with kallar grass and rice. Plant Soil 1997, 194, 37-44. [CrossRef]

43. Ravindranath, N.H. Mitigation and adaptation synergy in forest sector. Mitig. Adapt. Strat. Glob. Chang. 2007, 12, 843-853. [CrossRef]

44. Grouzis, M.; Akpo, L.E. Influence d'Acacia raddiana sur la structure et le fonctionnement de la strate herbacée dans le Ferlo sénégalais. In Un Arbre au Désert; Le Floc'H, É., Ed.; IRD Éditions; OpenEdition: Marseille, France, 2003; pp. 249-262.

(C) 2020 by the authors. Licensee MDPI, Basel, Switzerland. This article is an open access article distributed under the terms and conditions of the Creative Commons Attribution (CC BY) license (http://creativecommons.org/licenses/by/4.0/). 